\title{
Memorialising and Commemorating Traumatic Past: Diary of a Guerrilla Girl
}

\author{
Badri Prasad Pokharel, Ph. D ${ }^{1}$.
}

\begin{abstract}
This article makes an attempt to analyze Tara Rai's Chhapamar Yubatiko Dayari (The Diary of a Guerrilla Girl) with the help of trauma theory. It is a memoir which unfolds many hidden parts of a combatant as his/her testimony to signify the traumatic memory. Past events related to war and conflicts always bring a horrible consequence to the survivors who, if anything can, remember these historical events as an act of witnessing the painful traumatic events as a psychological need and a social duty to reminisce those who died in the battle. Testimony, expressed about those events would bring afore the facts which, otherwise, may not be known. In doing so, I have used the critical insights of Caruth and other trauma theorists to illustrate the historical role in understanding the psychological response to war trauma in the form of testimony. It is important to elucidate the social factors which play a pivotal role in psychological understanding and building together to develop the concept of the personal narrative.
\end{abstract}

Key Words: commemoration, People's War, reminiscence, testimony, trauma, witnessing

\section{Introduction}

In this article, I have accessed Chhapamar Yubatiko Dayari (Diary of a Guerrilla Girl) - the memoir of an ex-Maoist combatant, Tara Rai who fought in the ten-years long People's War instigated by the then Nepal Communist Party (Maoist) as a member of cultural troupe and arrested by the security personnel and spent a long time in jails by applying trauma theory developed by Cathy Caruth and others. This book is a testimony of a combatant who worked as a Maoist guerrilla in the People's War and went through severe ups and downs. It helps to reshape the historical significance in readers' mind.

It's human society which always uses memorials to infuse each one to remember the past events or people which or who were even more horrible to them to reminisce at

1 Dr. Pokharel is an Associate Professor of English at Saraswati Multiple Campus, Lainchour, Kathmandu, T. U. 
present time. Such memorials may be instituted by the state or by common people, which can be public or private, but would be a property of those who are directly or indirectly related to them and can hardly forget them in spite of their several attempts. Commemoration will be a fine word to explain this situation, that is probably "the most heavily trafficked point of intersection between history, sociology and political science and the place of commemoration in the construction of group, particularly national identities"(Hutt, 2012, p. 172). Human psychology is another important factor that entices personal memory and befits within the social context of such events. People's War, for example, which lasted for more than ten years, ended about thirteen years ago with Comprehensive Peace Treaty (CPT) and the party which had enticed it has been in the mainstream political arena and contesting in the Constitutional Assembly(CA) elections, is instituted as a glorious event for those who strongly participated in it with sound enthusiasm. This war, along with a lot of acts of witnessing and presenting them in the form of testimony, is now institutional and public because commemorating is an attempt to ensure the memories of particular individuals or groups or places which will be remembered by later generations, perhaps with the fear that they are being forgotten. Hutt (2012) further elucidates, "Memorials help us to remember the wars and the people they commemorate. They are society's ways of reminding us of war"(p.173). The past events would help one weave for future and make him or her go ahead with limelight.

\section{Trauma and Testimony}

Trauma, as formulated by Sigmond Freud, is related to unconscious; and the traumatic event may trigger past traumatic happenings, perhaps mixed with fantasy, and how the current event is experienced. Talking more about trauma, Kaplan (2005) states, "There may in the case of battle trauma, be unconscious guilt at surviving an attack; or events in battle may unconsciously recall childhood violence where the victim wished for a sibling's death, etc." (p.32),such traumatic events may fall into the arena of repression and can be brought into normality. But sharing such events in literary forms would be very meaningful through hearing, reading, or viewing accounts that "make apparent personal engagement with history" (Simon, 1997, p.1). These accounts comprise of diaries or eyewitness statement, documentary photographs or film, novels, poetry, stories and even fictionalized representations as testimony. The main concern for such testimonies would be to convey through multiple expressive forms, that bring the historical substance and significance of prior events and trauma "a sudden depression of the nervous system or nervous exhaustion produced by violent emotion" (Wastell, 2005, p.xvi). To explain more about the importance 
of testimony, Simon (1997) further expresses, "Testimony thus comprises representations ether by those who have lived through such event or by those who have been told or shown such lived realities, either directly or indirectly" (p.1). They have been moved to convey to others what has been impressed upon them for some span of time.

Societies have always used the past traumatic events as memorials to help them to remember them time and again. Relating them to the way to commemoration, Hunt (2004) points out, "It is probably the most heavily trafficked point of intersection between history, sociology and political science and the place of commemoration in the construction of group, particularly national identities" (p.172). Psychology also has an important role to play here, as it is concerned with the role of individual memory and how the individual fits within the social context of such events. Memorials can be "instituted by the state or by private individuals; they can be public or private" (ibid). To take an example, war graves, instituted in their present form after the wars, are uniform except for the message at the base, where families are permitted to add a short message; even these testimonies employ a common social discourse, with the same phrases occurring repeatedly. The graves are institutional and public as seen as testimony which "addresses what in history is action that exceeds any substantialised significance, and what in happenings is impact that dynamically explodes any conceptual reifications and any conative delimitations"(Fellman, 1992, p.5). Referring the past events as a form of testimony, one would drag the significance of the history.

People commemorate the past even if it is 'grief-stricken' trauma of what Wastell (2001) addresses as "an emotional shock, producing a disturbance, more or lessen during of mental functions" (p.xvi); to those who survived it because it is the nostalgic dimension of these devotional institutions. There remains a renewed attention in society to relationship between memory, commemoration and identity and also a passion for recovery and discovery of collective and individual 'pasts', which are brought into "the service of constructing and mentioned identities in a new memory politics(Ray, 2006, p. 135). Remembering the past one gets emotionally attached and mentally detached from the present and physically inactive in the works because the past in the present time has become an iconic as a valuable activity in or of itself. Many people as supporters and whole time workers (WTW) participated in People's Warand thousands of them lost their lives, relatives got physically maimed and have been impaired and at present living a 'helpless' life; as a result, these 'past' events have been an issue to remind them again and again even if they try to forget them. Bringing out some 
important facts about memory, Hunt (2004) further elucidates, "Memory exists along with a continuum of experience, with one end being individual and private memories kept alive in part by the development of individual narratives, and the other end being the collective cultural and public memories, which are kept alive at least in part through memorialization" (p.143). These memories have become a heritage to them as a means of preserving a fixed idea of the past. These horrible past events - sites of battles, deaths, burials of dead bodies etc. have been a part of their memorialisation and paying an unalienable tribute to them is a part of commemoration. When one remembers the war, he or she doesn't think of a particular individual or events, rather he or she remembers the whole event and its consequences that have brought so many changes in their present lives. As a part of witnessing, memories are "like discrete islands of precocious thinking and feel almost like the remembrances of another child, removed, yet connected in a complex way" (Laub, 1992, p.76). One's witnessing a historical event would be testimony for making an account of the past.

These fatal and grief-stricken events are no longer a horrible, rather they have become a property which can neither be looked nor be thrown but shared time and again be writing in the printed form as testimony; which "may serve as an expression of survival and loss, simultaneously aspiring to human continuity, the establishment of justice, the making of the future" (Simon, 1997, p.1). Expressing one's testimony would help feel much better.

\section{Diary of a Guerrilla Girl: a Testimony of Commemorating Traumatic Past}

Tara Rai 'Anmol', a member of Maoist's cultural troupe during the People's War, later arrested and put in jails of different places, has undergone with several traumatic experiences, encountering with death many times and facing the traumatized one after another spent about one year's suffering from her chronic disease - rheumatic heart disease - taking medicines and going through several checks and tests. All these events which she is able to imprint in a book form Chapamar Yuvatiko Dayari (Diary of a Guerrilla Girl) - published by one of the renown publishers of Nepal, Ratna Pustak Bhandar in May/June 2010 used to be a havoc traumatic experience while she was experiencing them, but now they have become a heritage of her identity. To quote her how she reminisces those events - "whether I was carrying a grenade in my waist or doing PT while carrying a rifle, my mother always there inside me" (Hutt, 2012, p. 124), she is still missing the situation which might be intolerable that time longing for her mother, but at present time the nostalgic experience longing for mother has become an icon to lead her life ahead. The moment when she was in 
army camp and had to spend the night with them having the food given to her with hands tied from backside was really painstaking to her as she spent each moment being chaotic and ambiguous about her own and her friends' lives. Expressing her traumatic experience of her sojourn in rebellion path, Rai (2010) brings forth, "In barrack how people were targeted whether they are cow grazers, innocent girls or even peddlers, they are the real victims" (p.37). Here, Tara was in such condition whether she could be alive or not she spent each moment in such pathetic condition. But at present, speaking on a media program Karabasaka Samjhana, a radio program being broadcasted from Ilam, she is sharing her experience with her audience telling them how painful the situation was that time, which anyone could hardly undergo with; on the other hand, memorialising these events in the form of the radio program, she is commemorating the past which would enable her to sustain her life, her career of writing memoirs and other fiction works and on the whole making her survive with a social identity. Likewise, when she was arrested and detained by the army, her comrades were also arrested along with her and later killed and buried in front of her with a threat that they would bury her too if she would not tell them about her other comrades' whereabouts. This clearly indicates how she was able to bear the pangs she had. Her comrades Suresh and Ruben who involved in this war to liberate people from the chains of several bonds and dreamt to have a land of dreams have been lying dead on the ground with wounds in different parts of their bodies. With the span of time, these comrades have become 'martyrs' or 'shining stars' for other comrades. They sacrificed for the nation as well as liberation ofthe people who have been the victims of different kinds of discrimination and segregation. War either civil war or other always brings similar kinds of horrible consequences in survivors' lives, who live remembering their near and dear ones even for a long time. But with the span of time, these horrible consequences become a matter of their personal property as long as they remain alive. Now, the life of Ruben and Suresh for Tara Rai is almost respected one among many others. They remain in her memory as long as she remains alive. These comrades are remembered as an icon of 'wellbeing' unlike those who killed them. She spent short time in army detention and had to sign a confession and was handed over to police, who later delivered her to the first of a series of jails Ilam, Jhapa and Morang. As a young woman of slightly built, suffering from a heart complaint and needing medication every moment, she is also subjected to physical brutality, but on the other hand she still recalls numerous acts of kindness from her fellow prisoners. 
Tara Rai, an ordinary girl whose family background is unsettled: her father deserted the family when she was only ten years old and she and her mother were obliged to live at her maternal uncle's home until her father returned home six years later. With some difficulties, she quitted school and remained in disgrace for some time, which she had to spend her days grazing the family's goats at the hillside around her village and had to leave the village to live in a Maoist camp with other children from her school. As she had long aspired to become a singer, she was selected a member of the party's cultural troupe. One event - two drunkards misbehaved her and her family with a threat that they would report to police against them - changed her understanding the beaurgouise thinking herself of proletariat and decided to fight against such exploiters on the behalf of oppressed class. She could not work for the party for a long time as she was arrested, kept on detention for a long time, sent to jails of different places and underwent through series of traumatic experiences. These all events were beyond the toleration for her but she didn't have other options except that, on the contrary, these traumatic experiences after imprinting in the form of books have become a matter of memorialisation and commemoration for her life till now and onwards. She wrote the book Chapamar Yuvatiko Dayari and some national dailies' reporters like Devendra Bhattarai, Ujjwal Prasai, Girish Giri, literary figures like Ganesh Rasik encouraged her to become a good writer. Ratna Pustak Bhandar became ready to bring out her traumatic experiences she faced during her detention and prison life. Thousands of copies of this book were printed in its first edition. By the time of the book's launch on 31 July, 2010, one month after the book's publication, the first edition's all copies were sold out. Different speakers such as Dharmashila Chapagai, the then member of Constitutional Assembly, who was her close aide in the jails, Tara Rai herself, reporters from different newspapers spoke on her behalf. Reciting her traumatic experience to them, she made everyone participate in the program weep and the whole scenario looked very grieved. Illuminating the glorious moments Tara Rai was getting on as a prolific writer, Hutt (2010) further states, "The launch and coverage it (the book) received in Kathmandu Media ensured that the book continued to sell and the only two weeks later Tara Rai had to discontinue signing the copies at the National Booksellers and Publishers annual book exhibition in Kathmandu 
because the second edition had sold out" (p.135). This way memorialising the horrible past events as a form of commemoration has become significant to her as a writer that would settle her for a long time in the literary world. And this book in short time, more than ten thousand copies have been sold out, "this has been a much bigger success than any other conflict memoirs" (Ibid 114). Unless she had used all her traumatic experiences as a process of memorialisation, no one would have known her as Tara Rai, a writer and these unbearable pangs she underwent during the detention and jail period have been a heritage or property she has ever earned in her life and how commemorating them one after another either through the media or paper has been fortunate to her. Her witnessing the past of a historical event which may signify the whole of the history and presenting it in the form of printed book as testimony would bring the fact that the rebels who, once raised the weapons and ammunition for the sake of the nation, liberation of many underprivileged groups and complete republican society and always remained on edge of the sword, have turned into active members of civil society and preaching for peace and solidarity for others.

\section{Conclusion}

In bringing out some important personal or national issues in the printed form, one's witnessing and testimony would play important role to let the other know about the traumatic past that once shook the human dimensional approach and left one in battered condition from which he or she would not even think of coming out. In the same condition, Tara Rai being harassed, disappointed, mentally and physically tortured except in some occasions of consolations from some army staff, was able to succumb all these pangs as a reward for her involvement in People's War thinking that everyone had to go through it, but with the span of time these grief-stricken traumatic pains have become a fruitful denouement on the whole, which ultimately brought her a good identity, name, fame, respect, money and at last a way of living the rest of her life, besides, for many others like her whom the society would not regard as capable of contributing society, her traumatic experience can enhance the way to succeed in spite of thorny path. 


\section{References}

Felman, S. (1992). Education and Crisis, or the Vicissitudes of Teaching. In S. Fellman and D. Laub (Eds), Testimony Crisis of Witnessing in Literature, Psychoanalysis and History(pp.1-56). New York and London: Rutledge.

Hunt, N. O. (2004). Memory, War and Trauma. New York: Cambridge.

Hutt, M. (2012). Reading Nepali Maoist Memoirs. Studies in Nepali History and Society, 17(1), 32-43.

Kaplan, E. A. (2005).Trauma Culture the Politics of Terror and Loss in Media and Literature. New Brunswick: Rutgers UP.

Laub, D. (1992). Bearing Witness, or the Vicissitudes of Listening. In S. Fellman and D. Laub

(Eds), TestimonyCrisis of Witnessing in Literature, Psychoanalysis and History

(pp.57-74). New York and London: Routledge.

Rai,T. (2010). Chapamar Yuvatiko Dayari. Kathmandu: RatnaPustakBhandar.

Ray, L. (2006). Mourning, Melancholia and Violence.In D. Bell (Ed), Memory, Trauma and World Politics. New York: Palgrave MacMillan.

Wastell, C. (2005). Understanding Trauma and Emotion Dealing with Trauma with Emotion Focused Approach.Crow's Nest NSW: Allen \& Unwin. 